\title{
SISTEM PEMBUKTIAN DALAM PENANGANAN PERKARA PERSELISIHAN HASIL PEMILIHAN UMUM KEPALA DAERAH DAN WAKIL KEPALA DAERAH (PEMILUKADA) DI MAHKAMAH KONSTITUSI
}

\author{
Safi' \\ Fakultas Hukum Universitas Trunojoyo \\ E-mail : syafik41@yahoo.com
}

\begin{abstract}
The choice of a system of proof in the case handling process within the judiciary is a very important thing. Because the verification system adopted by a judicial institution will determine the quality of the verdict to be taken. Verification system adopted by the Constitutional Court in handling cases disputes the results of the regional head elections as stipulated in Act. No. 24 Th. 2003 had the right to find a material truth which is expected.
\end{abstract}

Key words: verification, constitutional court, material truth.

\begin{abstract}
Abstrak
Pilihan sistem pembuktian dalam penanganan perkara perselisihan hasil Pemilukada melalui lembaga peradilan adalah hal yang penting karena sistem verifikasi yang diadopsi dari lembaga peradilan akan menentukan kualitas putusan hakim. Sistem verifikasi diadopsi oleh Mahkamah Konstitusi dalam menangani perkara perselisihan hasil pemilihan umum sesuai dengan ketentuan dalam Undangundang No. 24 Tahun 2003 yaitu hak untuk menemukan kebenaran yang diharapkan.
\end{abstract}

Kata Kunci: verifikasi, mahkamah konstitusi, bahan hukum.

\section{Pendahuluan}

Pemilihan umum atau disebut Pemilu adalah bagian dari pelaksanaan prinsip demokrasi yang disebut dalam UUD 1945 Pasal 22E. ${ }^{1}$ Oleh karenanya Negara yang menyatakan diri sebagai Negara demokrasi dalam konstitusinya, pasti melaksanakan kegiatan pemilu untuk memilih pemimpin Negara atau pejabat publik yang baru. Dalam pelaksanaan prinsip demokrasi tersebut ada yang baru dalam pelaksanaan otonomi daerah, sejak diterbitkannya UU No. 32 tahun 2004 tentang Pemerintahan Daerah sebagai ganti dari UU No. 22 tahun 1999 yang berlaku sebelumnya. Hal baru tersebut adalah Perkembangan berdemokrasi di daerah yaitu seluruh kepala daerah dipilih secara langsung oleh rakyat sesuai dengan amanat undang-undang tersebut, kecuali jaba-

\footnotetext{
1 Taufi Qurrohman Syahuri, "Putusan Mahkamah Konstitusi Tentang Perselisihan Hasil Penghitungan Suara Pemilihan Umum Berdasarkan Undang-Undang No. $24 \mathrm{Ta}$ hun 2003" J urnal Konstitusi PKK-FH Universitas Bengkulu, Vol. II, No. 1, J uni 2009, hlm. 9
}

tan Gubernur Daerah Istimewa Yogyakarta dan Walikota di Daerah Khusus Ibukota Jakarta. Perubahan pranata hukum pemilu yang mengedepan dalam dua dasa warsa terakhir yang dapat kita lihat dalam kehidupan bangsa ini adalah adanya perubahan yang sangat essesial, baik yang menyangkut pengakuan atas hak-hak individu sebagai warga negara maupun perubahan dalam struktur kelembagaan negara. ${ }^{2}$

Jimly Asshiddiqie merumuskan tujuan penyelenggaraan pemilu menjadi 4 (empat). Pertama, untuk memungkinkan terjadinya peralihan kepemimpinan pemerintahan secara tertib dan damai; kedua, untuk memungkinkan terjadinya pergantian pejabat yang akan mewakili kepentingan rakyat di lembaga perwakilan; ketiga, untuk melaksanakan prinsip kedaulatan rakyat; dan keempat, untuk melak-

\footnotetext{
2 I Nyoman Budiana, "Reinterpretasi Sistem Pemilu Sebagai Implementasi Kedaulatan Rakyat Di Indonesia", J urnal Konstitusi PKK Fakultas Hukum Universitas Pattimura, Vol. li, No. 1, J uni 2009, hlm. 31.
} 
sanakan prinsip hak-hak asasi warga negara. ${ }^{3}$ Oleh karena itu, Pemilukada memiliki posisi yang strategis dalam membangun demo-krasi dalam masa transisi, agar Pemilukada tersebut memiliki daya ungkit yang besar dalam menciptakan demokrasi yang bermartabat yang penyelenggaraannya harus mengacu pada prinsip mandiri; jujur; adil; kepastian hukum; tertib penyelenggara Pemilu; kepentingan umum; keterbukaan; proporsionalitas; profesionalitas; akunta-bilitas; efisiensi; dan efektifitas. ${ }^{4}$

Perkembangan demokrasi tersebut selaras dengan amandemen UUD 1945 yang telah memutuskan Pemilihan Umum Presiden dan Wakil Presiden secara langsung. Asas pemilihan kepala Daerah dan Wakil Kepala Daerah secara eksplisit tidak dirumuskan dalam UndangUndang Dasar 1945 sebagai-mana asas pemilihan umum, tetapi terdapat dalam pasal 56 ayat (1) UU No. 32 Tahun 2004 yang menyatakan: kepala daerah dan wakil kepala daerah dipilih dalam satu pasangan calon yang dilaksanakan secara demokratis berdasarkan asas langsung, umum, bebas, rahasia, jujur, dan adil. ${ }^{5}$ Terkait dengan pemilihan kepala daerah maka caIon haruslah berdasarkan usulan partai politik atau gabungan partai politik yang memenuhi syarat minimal tertentu dalam perolehan suara dan kursi di parlemen. ${ }^{6}$ Pasal ini juga dijadikan sebagai pertimbangan dan mengambil putusan dalam perkara pemilu Kepala Daerah. ${ }^{7}$ Dan juga Mahkamah Konstitusi tidak akan berani mengambil putusan dengan menggabungkan kewenangan Mahkamah Konstitusi yaitu penyelesaian sengketa hasil pemilu dan pembubaran partai politik secara sekaligus sehing-

\footnotetext{
${ }^{3}$ Didik Sukriono, "Menggagas Sistem Pemilihan Umum Di Indonesia", J urnal Konstitusi PKK Universitas Kanjuruhan Malang, Vol. II, No. 1, J uni 2009. hlm. 20.

${ }^{4}$ Zainal Arifin Hoesein, "Pemilu Kepala Daerah dalam Transisi Demokrasi", J urnal Konstitusi, Vol. 7, Nomor 6, Desember 2010, hlm. 4.

${ }^{5}$ Hendra Sudrajat, "Kewenangan Mahkamah Konstitusi Mengadili Perselisihan Hasil Pemilukada", J urnal Konstitusi, Volume 7, Nomor 4, Agustus 2010, hlm. 175.

${ }^{6}$ Retno Saraswati, "Calon Perseorangan Dalam Pilkada Suatu Tinjauan Filosofis", J urnal Konstitusi PPK Fakultas Hukum Universitas Brawijaya, Vol. II, No. 1, J uni 2009, hlm. 76.

Ardilafiza, "Pemilu Yang Demokratis?", Jurnal Konstitusi PKK-FH Universitas Bengkulu, Vol. II, No. 1, J uni 2009 , hlm. 64.
}

ga penyelesaian sengketa dapat dituntaskan secara substantif. ${ }^{8}$

Seperti lazimnya Pemilu lainnya di beberapa daerah pelaksanaan Pemilihan Umum Kepala Daerah melahirkan ketidakpuasan meluas yang berujung pada pengajuan keberatan atas hasil Pemilu Kepala Daerah dan Wakil Kepala Daerah (Pemilukada) tersebut ke pengadilan (Mahkamah Konstitusi) dengan alasan yang beragam. Di Jawa Timur misalnya, kabupaten/ kota yang telah menyelenggarakan Pemilu Kepala Daerah berujung dengan gugatan atas sengketa hasil pemilihan kepada Mahkamah Konstitusi, diantaranya yaitu: Kabupaten Malang, Lumajang, Banyuwangi, J ember, Gresik, kota Surabaya, dan Sumenep, dengan putusan yang bermacam-macam. Ada yang putusannya menolak permohonan secara keseluruhan, seperti di Sumenep, Jember, Banyuwangi, dan Lumajang, ada pula yang putusannya mengabulkan sebagian permohonan dengan memerintahkan pemungutan suara ulang dibeberapa wilayah/ kecamatan seperti Gresik dan Surabaya. Perhatian publik tersita dengan adalah penanganan sengketa hasil Pemilihan Umum Gubernur dan Wakil Gubernur Jawa Timur pada tahun 2008-2009 tahun lalu. Hal tersebut menarik karena merupakan Pemilihan Umum Gubernur dan Wakil Gubernur pertama yang ditangani oleh Mahkamah Konstitusi (karena sebelumnya sengketa hasil Pemilihan Kepala Daerah ditangani oleh Mahkamah Agung/ MA) serta penilaian Mahkamah Konstitusi yang menyatakan telah terjadi pelanggaran serius yang bersifat terstruktur, sistematis, dan massif. Dalam putusan Nomor 41/ PHPU.D-VI/2008, MK memerintahkan KPU Propinsi J awa timur untuk melakukan perhitungan dan pemungutan suara ulang di beberapa daerah yang frekuensi pelanggarannya cukup serius, terstruktur dan sistematis, yaitu penghitungan ulang untuk Kab. Pamekasan, dan pemungutan suara ulang untuk Kab. Bangkalan dan Sampang.

Putusan MK Nomor 41/ PHPU.D-VI/ 2008 ini memicu polemik yang begitu luas khususnya di Jawa Timur, karena dinilai MK telah

\footnotetext{
${ }^{8}$ Ibid.
} 
melampaui kewenangannya dalam menangani sengketa Pemilu Kepala Daerah sebagaimana diatur dalam UU No. 32 tahun 2004 yang telah diubah dengan UU No. 12 tahun 2008 tentang Pemerintahan Daerah. Sebelumnya di berbagai daerah lain juga mengalami hal yang sama, di Maluku Utara misalnya, penyelenggaraan pemilihan Kepala Daerah telah menimbulkan kekacauan dan berakhir dengan menyisakan sejumlah permasalahan. Bahkan, pihak KPUD Maluku Utara dipandang tidak mampu melaksanakan pemilihan Kepala Daerah sesuai dengan aturan yang berlaku. Hasil penghitungan suara yang diperoleh masing-masing calon kepala daerah menimbulkan kontroversi. Akibatnya, KPU Pusat mengambil alih peran untuk melakukan penghitungan ulang.

Intervensi KPU Pusat berupa pengambil alihan kewenangan berawal dari keterangan KPU Provinsi Maluku Utara dengan KPUD Kabupaten/Kota Malut terkait kesimpangsiuran penandatanganan dua dokumen. Ada dua dokumen sertifikat perhitungan suara yang sama, tetapi dengan angka perhitungan yang berbeda. Hal ini nampak aneh karena sudah jelas angkanya berbeda tetapi penandatanganannya sama. Buah intervensi tersebut menghasilkan penetapan hasil pemilihan kepala daerah Maluku Utara oleh KPU Pusat dan membatalkan penetapan KPUD Provinsi Maluku Utara. ${ }^{9}$

KPU Pusat dalam soal pengambilalihan, menggunakan Pasal 122 ayat (3) UU No 22 Tahun 2007 yang menyebutkan bahwa apabila terjadi hal-hal yang mengakibatkan KPU Provinsi atau KPU Kabupaten/Kota tidak dapat menjalankan tugasnya, tahapan penyelenggaraan Pemilu untuk sementara dilaksanakan oleh KPU setingkat di atasnya. Persoalannya, KPU Provinsi Maluku Utara berhasil menjalankan tugasnya, bahkan sudah mengumumkan pemenang Pilkada. Jadi, tidak ada kriteria yang membuktikan bahwa KPU Provinsi Maluku Utara tidak dapat menjalankan tugasnya, karena telah dibuktikan dengan selesainya semua tahapan Pilkada sampai dikeluarkannya Keputusan KPU Provinsi Maluku Utara No. 20/Kep/

\footnotetext{
9 Koran Sindo, 23 November 2007
}

PGWG/ 2007 pada tanggal 16 November 2007, KPUD Malut yang telah menetapkan pasangan Thaib-Abdul sebagai pemenang pilkada Gubernur Malut.

Pasal 122 ayat (3) di atas sebenarnya memberikan celah kepada KPU Pusat untuk mengambil alih tugas KPU Provinsi dan KPU Kabupaten. Tetapi, pengaturannya tidak jelas. Tidak dijelaskan secara rinci dalam kondisi dan alasan apa KPU Pusat dapat mengambil alih tugas KPUD tersebut. Apakah dapat dibenarkan apabila KPU Pusat bersandar pada Pasal 122 ayat (3) untuk mengambil alih kewenangan KPUD dan melakukan rekapitulasi suara pemilihan Gubernur/Wakil Gubernur dengan alasan rapat pleno KPUD Maluku Utara beberapa kali mengalami jalan buntu. J elas bahwa dalam persoalan ini KPU Pusat bertindak atas dasar pertimbangan dan penafsiran sendiri sebab tidak ada satu pasal pun dalam UU No 32 Tahun 2004, PP No 6 Tahun 2007 dan UU No 22 tahun 2007 yang memberikan kewenangan kepada KPU Pusat untuk mengadakan rekapitulasi ulang, apalagi menetapkan pasangan calon terpilih Gubernur/ Wakil Gubernur.

Kasus sengketa pilkada yang lain terjadi di Sulawesi Selatan. Sengketa yang berujung pada putusan MA tersebut diputuskan untuk dilakukan pemungutan suara ulang di daerah pemilihan Kabupaten Gowa, Bone, Bantaeng dan Tana Toraja. MA menengarai telah terjadi penggelembungan suara di beberapa daerah tersebut. Namun, putusan PK dari MA menyatakan hakim keliru menerapkan hukum dalam sengketa pilkada Sulsel. Disebutkan, yang berwenang untuk memutuskan dilakukan perhitungan suara dan pemungutan ulang adalah panitia pemilih kecamatan (PPK), penggelembungan jumlah daftar pemilih tetap pada hakikatnya menjadi wewenang Panitia Pengawas Pemilihan untuk menanganinya. MA memutuskan menolak keberatan yang disampaikan pasangan calon gubernur Amin Syam dan calon wakil gubernur Mansyur Ramly. Putusan yang dikeluarkan melalui rapat permusyawaratan MA itu dipimpin langsung Ketua MA, Bagir Manan, tertanggal 18 Maret 2008. Dengan demikian, pasangan pemenang Pilkada Sulsel ditetap- 
kan kepada Syahrul Yasin Limpo dan Agus Arifin Nu'mang (Sayang) yang terpilih pada November 2007. ${ }^{10}$

Berbeda dengan sengketa pilkada Depok. Awal konflik pilkada Depok ketika salah satu pasangan dari lima pasangan, yaitu Badrul Kamal-Syihabuddin Ahmad mengajukan keberatan ke Pengadilan Tinggi J awa Barat pada 11 Juli 2005 dengan menggugat KPU Kota Depok. Alasannya, terdapat kesalahan perhitungan suara sehingga pasangan itu dirugikan. Sebelumnya, KPU Depok mengumumkan hasil perhitungan suara pilkada 2005. Pasangan Nur Mahmudi Isma'il-Yuyun Wirasaputra meraih 232. 610 suara atau 43,90 persen, disusul pasangan Badrul Kamal-Syihabuddin Ahmad 206. 781 suara (39,03 persen), Yus Ruswandi-Soetadi Dipowongso 34.096 (6,44 persen), Abdul Wahab Abidin-Ilham Wijaya 32.481 suara $(6,13$ persen) dan Harun Heryana-Farkhan 23.850 (4,5 persen). ${ }^{11}$

Pada 4 Agustus 2005, Pengadilan Tinggi Jawa Barat mengeluarkan putusan No 01/ Pilkada/2005/PT Bandung yang mengabulkan permohonan dari pemohon dan menyatakan batal hasil perhitungan suara $6 \mathrm{~J}$ uli 2005 serta menetapkan jumlah perhitungan suara yang benar, yaitu suara Badrul Kamal-Sihabuddin Ahmad menjadi 269.551, sedangan suara Nur Mahmudi Isma'il turun menjadi 204.828. Keputusan inipun menganulir kemenangan pasangan Nur Mahmudi-Yuyun W dan memenangkan pasangan Badrul Kamal-Syihabuddin.

Atas putusan PT J abar tersebut, KPU Depok menolak dan mengajukan memori Peninjauan Kembali (PK) ke Mahkamah Agung (MA) pada 16 Agustus 2005. Pada 8 September 2005 MA mengumumkan pembentukan Majelis PK perkara sengketa Pilkada Depok dan menetapkan lima hakim agung. MA akhirnya memutuskan mengabulkan permohonan PK dari KPU Depok, membatalkan putusan PT J abar di Bandung tanggal 4 Agustus 2005, dan menolak keberatan dari permohonan Badrul Kamal-Syihabuddin inwal pilkada Depok. Dengan putusan MA ini berarti Nur Mahmudi Isma'il-Yuyun Wi-

\footnotetext{
10 Koran J awa Pos, 19 Maret 2008

11 Kompas Cibermedia 26 juli 2006
}

rasaputra sah dan punya kekuatan hukum yang tetap sebagai Walikota dan Wakil Walikota Depok. Pada 3 J anuari 2006, pasangan Badrul Kamal mengajukan permohonan keberatan atas putusan MA ke Mahmakah Konstutusi (MK). Oleh MK, sengketa (pilkada) ini merupakan wewenang MA.

UU No 32 Tahun 2004 tentang Pemerintahan Daerah menyatakan bahwa penyelesaian sengketa pilkada diserahkan melalui proses hukum di Mahkamah Agung di satu sisi. Sementara, di sisi lain putusan sengketa pemilihan kepala daerah oleh Mahkamah Agung di beberapa daerah menuai kontroversi. Sebagai contoh, putusan sengketa Pilkada Sulawesi Selatan (Sulsel), Maluku Utara (Malut) dan pilkada Depok yang berbuntut kontroversi tersebut menunjukkan ketidakjelasan putusan hukum yang di-keluarkan oleh Mahkamah Agung (MA). Padahal putusan itu seharusnya mencerminkan penye-lesaian terakhir sengketa pilkada.

Harapan adanya putusan hukum yang mengikat dan bisa dihormati semua pihak yang bersengketa nampaknya sulit dicapai. Putusan Mahkamah Agung yang memerintahkan dilakukannya pilkada ulang atau perhitungan ulang hasilnya digugat lagi. Tentu saja persoalan akan bertambah runyam. Hal ini mengingat prosedur beracara di Mahkamah Agung berjenjang dan putusan yang diambil masih memungkinkan dilakukan upaya hukum yang lain. Wajar apabila banyak orang yang menggugat putusan MA. Hal ini yang menyebabkan tingkat kepercayaan publik terhadap MA agak rendah, dan banyak pihak yang berkeinginan agar penyelesaian sengketa pilkada dialihkan kepada Mahkamah Konstitusi sebagaimana sengketa hasil pemilihan umum lainnya. Agar putusan penyelesaian perkara pemilihan umum kepala daerah tersebut cepat terselesaikan dengan putusan yang berfinal dan mengikat. Sifat putusan Mahkamah Konstitusi yang final diartikan bahwa tidak ada upaya hukum lain lagi, oleh karenanya putusan tersebut telah memiliki kekuatan mengikat secara umum dimana semua pihak harus tunduk dan taat melaksanakan putusan tersebut, walaupun ada pihak-pihak tertentu yang merasa keadilannya terganggu. Pu- 
tusan Mahkamah Konstitusi yang final dan mengikat akan dikaji dari aspek makna hukum, kekuatan memaksa dan akibat hukumnya. ${ }^{12}$

Perbedaan rezim pilkada antara Pemda dan Pemilu kemudian melebur, ketika MK mengeluarkan Putusan No. 72 - 73/ PUU/ 2004 tentang Pengujian UU No. 32 Tahun 2004. ${ }^{13}$ Putusan tersebut menjadi penengah antara perbedaan pendapat tentang rezim Pilkada, apakah dikategorikan sebagai rezim Pemilu atau justru Rezim Pemda. ${ }^{14}$ Pilkada kemudian dimasukan dalam rezim Pemilu. Perubahan rezim tersebut yang kemudian mendasari kewenangan konstitusional MK dalam menyelesaikan perselisihan hasil pemilukada. Dengan masuknya kewenangan pilkada dalam rezim pemilu, maka menjadi logis jika kewenangan perselisihan hasil pemilukada diserahkan kepada MK.

Harapan tersebut akhirnya menjadi kenyataan setelah lahirnya UU Nomor 22 Tahun 2007 tentang Penyelenggaraan Pemilu, pada pasal 1 angka 4 telah dengan tegas mendefinisikan pemilihan kepala daerah secara langsung sebagai pemilihan umum kepala daerah. Artinya dengan terbitnya UU No. 22 tahun 2007 ini pemilihan kepala daerah secara langsung sudah dengan tegas dimasukkan sebagai bagian dari rezim pemilihan umum, bukan seperti sebelumnya yang menjadi bagian dari rezim pemerintahan daerah. Hal tersebut kemudian dipertegas dengan terbitnya UU Nomor 12 tahun 2008 tentang Perubahan UU Nomor 32 tahun 2004 tentang Pemerintahan Daerah, khususnya pasal 236C yang dengan tegas mengatur bahwa kewenangan mengadili sengketa hasil penghitungan suara pemilihan kepala daerah dialihkan dari MK menjadi kewenangan MK. Dengan demikian walaupun MK baru di bentuk pada era reformasi, namun lembaga negara ini mempunyai kedudukan yang sederajat atau sama dengan lembaga negara yang lain yang telah ada sebelumnya, seperti Pre-

\footnotetext{
${ }^{12}$ Malik, "Telaah Makna Hukum Putusan Mahkamah Konstitusi yang Final dan Mengikat", J urnal Konstitusi, Vol. 6, Nomor 1, April 2009, hlm. 81.

${ }^{13}$ Veri J unaidi, "Pelanggaran Sistematis, Terstruktur dan Masif: Suatu Sebab Pembatalan Kehendak Rakyat dalam Pemilihan Kepala Daerah Tahun 2010", Jurnal Konstitusi, Vol. 7, Nomor 5, Oktober 2010, hlm. 42.

${ }^{14}$ lbid.
}

siden, DPR, dan MPR serta MA. Dengan kedudukan MK yang sederajat atau sama dengan lembaga negara lain dan adanya kesederajatan atau kesamaan kedudukan antarlembaga negara, maka pelaksanaan tugas konstitusional MK menjadi jauh lebih mudah dan lancar dalam memperkuat sistem checks and balances antarcabang kekuasaan negara. ${ }^{15}$

Perdebatan dan kontroversi terhadap putusan pengadilan dalam penanganan perkara PHPU Kepala Daerah baik waktu masih ditangani oleh Mahkamah Agung maupun waktu sudah menjadi kewenangan Mahkamah Konstitusi, diantaranya terkait dengan prosedur dan sistem pembukktian dalam penangan perkara PHPU Kepala Daerah tersebut, sehingga, bertolak dari latar belakang tersebut diatas, maka rumusan masalah yang akan dikaji melalui artikel ini adalah sebagai berikut: bagaimanakah sistem pembuktian dalam penanganan perkara perselisihan hasil pemilihan umum (PHPU) kepala daerah di Mahkamah Konstitusi?.

\section{Pembahasan}

\section{Kewenangan MK dalam Menangani Perkara Perselisihan Hasil Pemilihan Umum (PHPU) Kepala Daerah}

Menurut Topo Santoso, penegakan hukum pemilu, dapat ditempuh melalui 2 cara, yaitu civil process dan crime processs. ${ }^{16}$ Civil process merupakan mekanisme koreksi terhadap hasil pemilu, yang diajukan oleh peserta pemilu kepada lembaga peradilan yang berwenang. ${ }^{17}$ Mekanisme ini banyak ditempuh oleh peserta pemilu karena prosesnya yang cepat. Civil process cenderung lebih menarik dan membuka peluang yang besar untuk tercapainya tujuan penegakan hukum pemilu, karena dapat menganulir keputusan hasil pemilu. Bentuk kedua mekanisme penegakan hukum adalah crime process, yaitu proses penyelesai-

\footnotetext{
${ }^{15}$ Mariyadi Faqih, "Nilai-Nilai Filosofi Putusan Mahkamah Konstitusi Yang Final dan Mengikat", J urnal Konstitusi, Vol. 7, Nomor 3, J uni 2010, hlm. 109.

${ }^{16}$ Veri J unaidi, "Menata Sistem Penegakan Hukum Pemilu Demokratis Tinjauan Kewenangan MK atas Penyelesaian Perselisihan Hasil Pemilu", Jurnal Konstitusi, Vol. 6, Nomor 3, September 2009, hlm. 109.$$
17 \text { lbid. }
$$ 
an permasalahan hukum pemilu. ${ }^{18}$ Mekanime crime process seperti yang dikenal dengan penyelesaian pelanggaran atau sengketa pemilu melalui mekanisme hukum yang berlaku, baik pidana, administrasi maupun kode etik, sesuai dengan hukum acara yang berlaku. ${ }^{19}$

Berbeda dengan pemilu yang berlangsung sebelum Perubahan UUD 1945 yang tidak dapat dipersoalkan hasilnya oleh Peserta Pemilu, sesudah Perubahan UUD 1945, Pemilu yang diselenggarakan oleh suatu komisi pemilihan umum yang bersifat nasional, tetap, dan mandiri, dapat dipersoalkan hasilnya oleh peserta pemilu di forum MK sebagai "perselisihan hasil Pemilu"20. Dalam sistem peradilan perselisihan hasil pemilihan umum ini, penetapan Komisi Pemilihan Umum (KPU) atas hasil perhitungan suara dari pemilihan umum menjadi objectum litis atau objek sengketanya. ${ }^{21}$ Dengan demikian, dalam sistem peradilan ini, yang diperkarakan bukan mengenai tindak pelanggaran atau kecurangan yang terjadi selama proses pemilihan umum itu berlangsung.

Melalui UU Nomor 22 Tahun 2007 tentang Penyelenggaraan Pemilihan Umum, terminologi pemilihan kepala daerah diubah menjadi pemilihan umum kepala daerah. Bab I Pasal 1 angka 4 UU Nomor 22 Tahun 2007 mempunyai maksud bahwa Pemilu Kepala Daerah dan Wakil Kepala Daerah adalah Pemilu untuk memilih Kepala Daerah dan Wakil Kepala daerah secara langsung dalam negara Kesatuan Republik Indonesia berdasarkan Pancasila dan UUD 1945. Dengan demikian, apabila pemilihan kepala daerah sebelumnya menjadi perdebatan apakah masuk dalam rezim pemilu atau rezim pemerintahan daerah, maka dengan diterbitkannya UU Nomor 22 Tahun 2007 sudah jelas bahwa pemilihan kepala daerah secara langsung masuk dalam rezim Pemilu.

\footnotetext{
${ }^{18} \mathrm{Ibid}$.

19 lbid.

${ }^{20}$ A. Mukhtie Fajar, "Pemilu yang Demokratis dan Berkualitas: Penyelesaian Hukum Pelanggaran Pemilu dan PHPU", J urnal Konstitusi, Vol. 6 Nomor 1, April 2009, hIm. 12.

${ }^{21}$ Widodo Ekatjahjana, "Tinjauan Tentang Mekanisme Penyelesaian Perselisihan Hasil Pemilu Anggota DPR, DPD dan DPRD berdasarkan Peraturan Mk No. 16 Tahun 2009", J urnal Konstitusi PKKKD-FH Universitas Muhammadiyah Magelang, Vol. II, No. 1, J uni 2009, hlm. 8.
}

Konsekwensi yuridis penanganan sengketa hasil pemilihan kepala daerah menjadi kewenangan Mahkamah Konstitusi sesuai dengan Pasal 24C ayat (1) Perubahan UUD 1945. Peralihan kewenangan penyelesaian sengketa Pemilukada tersebut sebagaimana diatur dalam Pasal 236C UU Nomor 12 tahun 2008 yang menyatakan bahwa "Penanganan sengketa hasil penghitungan suara pemilihan kepala daerah dan wakil kepala daerah oleh Mahkamah Agung dialihkan kepada Mahkamah Konstitusi paling lama 18 (delapan belas) bulan sejak UndangUndang ini diundangkan."

Sebelum kewenangan tersebut dialihkan, MK mengeluarkan Putusan No. 72-73/ PUU-II/ 2004 tentang pengujian Undan-undang Pemerintahan Daerah yang mana MK menyatakan, “...secara konstitusional, pembuat undangundang dapat saja memastikan bahwa Pilkada langsung itu merupakan perluasan pengertian Pemilu sebagaimana dimaksud dalam Pasal 22E UUD 1945 sehingga karena itu, perselisihan mengenai hasilnya menjadi bagian dari kewenangan MK dengan ketentuan Pasal 24C ayat (1) UUD 1945. ${ }^{22}$ Namun pembentuk undangundang juga dapat menentukan bahwa Pilkada langsung itu bukan Pemilu dalam arti formal yang disebut dalam Pasal 22E UUD 1945 sehingga perselisihan hasilnya ditentukan sebagai tambahan kewenangan MA sebagaimana di mungkinkan Pasal 24A ayat (1) UUD 1945...". ${ }^{23}$ Tindak lanjut dari putusan MK tersebut, Pilkada dimasukkan oleh pembuat UU (DPR-Presiden) sebagai bagian dari Pemilu dalam UU 22 Tahun 2007 tentang Penyelenggara Pemilihan Umum. Pada Bab I Pasal 1 angka 4 UU 22/ 2007 dinyatakan, "Pemilu Kepala Daerah dan Wakil Kepala Daerah adalah Pemilu untuk memilih kepala daerah dan wakil kepala daerah secara langsung dalam Negara Kesatuan Republik Indonesia berdasarkan Pancasila dan UUD 1945". ${ }^{24}$

Jika ditelaah isi Pasal 236C UU No. 12 Tahun 2008 tersebut dari sudut bahasa hukum

\footnotetext{
${ }^{22}$ Abdul Ghoffar, "Kejujuran dalam Bingkai Hak MemilihDipilih (Pelajaran dari Pemilukada Bengkulu Selatan)", J urnal Konstitusi, Vol. 8, No. 1, Februari 2011, hlm. 74. 23 Ibid.

${ }^{24}$ Ibid.
} 
menimbulkan persoalan. Pertama, menurut Jimly Asshiddiqie, Pasal 236C mempunyai penafsiran ganda. Frase "paling lama" dalam kalimat tersebut praktiknya bisa lebih cepat (satu atau dua hari, pen), apalagi latar belakang munculnya Pasal itu semata-mata hanya ingin memberi waktu persiapan kepada MK. Misalnya, apabila dalam jangka waktu satu bulan sejak disahkan UU No. 12 Tahun 2008 MK sudah siap, maka perselisihan hasil Pilkada dapat langsung ditangani oleh MK. Penafsiran kedua, maksud "paling lama" adalah sebelum 18 bulan. Artinya, meskipun MK sudah mempunyai persiapan yang matang, sengketa tersebut tidak serta merta atau belum dapat dialihkan. Untuk memastikan mana yang benar, maka penafsiran ganda tersebut dapat dibawa ke MK untuk judicial review. Namun demikian, hal ini kemungkinannya kecil karena sulit mencari alasan konstitusionalnya. Untuk itu, J imly mengembalikan persoalan ini kepada pembentuk undang-undang yaitu Presiden dan DPR. ${ }^{25}$

Hal senada juga dikatakan oleh Bagir Manan, bahwa kata "paling lama" itu bisa jadi besok. Seharusnya isi pasal itu bukan menggunakan frase "paling lama" 18 bulan, melainkan dijelaskan dengan kalimat, semua sengketa pilkada yang sudah diselesaikan oleh MA, kemudian sengketa yang baru ditangani oleh MK. Dengan demikian, sebuah undang-undang akan memberikan kepastian dan konsisten. ${ }^{26}$

Kedua, sebuah pasal dalam undang-undang akan tetap dinyatakan berlaku apabila dalam undang-undang perubahannya tidak secara tegas dinyatakan telah dihapus atau diubah dengan rumusan pasal yang baru. UU No 12 Tahun 2008 tidak mengubah Pasal 106 UU No. 32 Tahun 2004 yang merupakan dasar kewenangan MA untuk memutus sengketa Pilkada. Pasal 106 ayat (1) UU No 32 Tahun 2004 di sebutkan, "Keberatan terhadap penetapan hasil pemilihan kepala daerah dan wakil kepala daerah hanya dapat diajukan oleh pasangan calon kepada MK dalam waktu paling lambat 3

\footnotetext{
${ }^{25}$ Mengkritisi revisi UU Pemda dari IImu Peraturan Perundang-undangan", http.www.hukumonline.com, diakses tanggal 5 Mei 2008

26 lbid.
}

(tiga) hari setelah penetapan hasil pemilihan kepala daerah dan wakil kepala daerah".

Pola pikir anggota DPR dalam membahas undang-undang tersebut keliru karena lebih mengedepankan proses peralihan dibandingkan dasar hukum utamanya, yakni Pasal 106. Hal tersebut akan menimbulkan kontradiksi substantif di dalam UU Pemda terbaru karena di satu sisi memuat teknis pengalihan tetapi di sisi lain justru "menjamin" kondisi awalnya tetap ada. Untuk mempertegas atau memberikan kapastian hukum tentang kewenangan penyelesaian sengketa pilkada masuk dalam wewenang MK dapat dilakukan dua cara. Pertama, diatur kembali dalam UU pilkada secara tersendiri dan menyatakan Pasal 106 ayat (1) UU No. 32 Tahun 2004 tidak berlaku atau; kedua, dapat dimasukkan ke dalam UU MK yang sekarang sedang direvisi. Dengan demikian, perdebatan akan hal tersebut dapat dihindari untuk menjamin adanya kepastian hukum.

Untuk melaksanakan ketentuan Pasal 236C UU No. 12 Tahun 2008 tentang Perubahan UU Nomor 32 Tahun 2004 tentang Pemerintahan Daerah, pada tanggal 29 Oktober 2008 Ketua MA dengan Ketua MK telah secara resmi menandatangani Berita Acara tentang pengalihan kewenangan mengadili perkara sengketa hasil pemilu kepala daerah/wakil kepala daerah dari Mahkamah Agung ke Mahkamah Konstitusi. Sebagai tindak lanjut dari ketentuan Pasal 236C UU No. 12 Tahun 2008 dan Berita Acara pengalihan kewenangan mengadili perkara sengketa hasil Pemilu kepala daerah dari MA ke MK, MK telah menerbitkan Peraturan Mahkamah Konstitusi (PMK) Nomor 15 Tahun 2008 tentang Pedoman Beracara dalam Perselisihan Hasil Pemilihan Umum Kepala Daerah.

PMK Nomor 15 tahun 2008 tegas menentukan bahwa obyek perkara yang menjadi kewenangan MK untuk mengadili adalah sengketa atau perselisihan hasil pemilihan umum kepala daerah antara yang ditetapkan Komisi Pemilihan Propinsi dan/atau Kabupaten/Kota dengan salah satu pasangan calon. Dengan demikian kewenangan untuk mengadili sengketa hasil pemilu kepala daerah sudah jelas menjadi kewenangan Mahkamah Konstitusi dengan obyek 
perkara adalah sengketa atau perselisihan hasil pemilihan umum kepala daerah.

Pasal 4 PMK No. 15 Tahun 2008 tentang Pedoman Beracara dalam Perselisihan Hasil Pemilihan Umum Kepala Daerah, dinyatakan bahwa obyek perselisihan pemilihan umum kepala daerah adalah hasil penghitungan suara yang ditetapkan oleh Komisi Pemilihan Umum Propinsi dan/atau Kabupaten/ Kota yang mempengaruhi; penentuan pasangan calon yang dapat mengikuti putaran kedua; dan terpilinnya pasangan calon kepala daerah dan wakil kepala daerah.

Tentang objek perkara yang berupa perselisihan hasil pemilihan umum kepala daerah ini, MK menerapkannya tidak secara kaku. Artinya, yang dimaksud dengan perselisihan hasil pemilihan umum kepala daerah itu tidak hanya penghitungan angka-angka yang ditetapkan oleh Komisi Pemilihan Umum Propinsi dan/ atau Kabupaten/Kota serta pengitungan angka-angka yang dilakukan oleh pasangan calon sebagai pemohon/penggugat, melainkan MK juga menyatakan berwenangan untuk mengadili pelanggaran yang cukup serius dan bersifat terstruktur, sistematis, dan massif yang berpengaruh secara langsung terhadap hasil penghitungan pemilihan umum kepala daerah. ${ }^{27}$ Beralihnya kewenangan penyelesaian sengketa pemilukada ke MK akan membawa harapan baru karena penyelesaian oleh MK relatif tidak menimbulkan konflik yang berarti. Hal ini dibuktikan dari pengalaman MK dalam menangani sengketa pemilu.

\section{Hukum Acara Penanganan Perkara PHPU Ke- pala Daerah di Mahkamah Konstitusi}

Sesuai dengan keberadaan, kedudukan dan fungsinya, Mahkamah Konstitusi diberi wewenang sebagaimana tercantum dalam Pasal 24C ayat (1) dan ayat (2) UUD 1945 yang ditegaskan kembali dalam Pasal 10 ayat (1) dan ayat (2) UU No. 24 Tahun 2003 tentang MK, yaitu mengadili pada tingkat pertama dan terakhir yang putusannya bersifat final untuk: menguji undang-undang terhadap UUD 1945,

\footnotetext{
${ }^{27}$ Lihat Putusan MK Nomor 41/PHPU.D-VI/2008 tentang Sengketan Hasil Pemilihan Umum Gubernur J awa Timur Putaran II.
}

memutus sengketa kewenangan lembaga negara yang kewenangannya diberikan oleh UUD 1945, memutus pembubaran partai politik, memutus perselisihan hasil pemilihan umum, dan wajib memberi putusan atas pendapat DPR mengenai dugaan pelanggaran oleh Presiden dan/atau wakil presiden menurut UUD 1945.

Untuk melaksanakan kelima kewenangan tersebut, maka diperlukan pengaturan tentang hukum acara yang sudah diatur dalam Pasal 28 sampai dengan Pasal 85 UU MK termasuk di dalamnya prosedur penanganan perkara perselisihan hasil Pemilu kepala daerah/ wakil kepala daerah, yang secara tekhnis diatur lebih lanjut dalam PMK No. 15 tahun 2008. Dalam PMK tersebut telah diatur secara detail prosedur penanganan perkara perselisihan hasil pemilu kepala daerah, termasuk di antaranya adalah proses pemeriksaan persidangan yang dilakukan dengan tahapan penjelasan permohonan dan perbaikan apabila dipandang perlu; jawaban termohon; keterangan pihak terkait apabila ada; pembuktian oleh pemohon, termohon, dan pihak terkait; dan kesimpulan (Pasal 8 ayat (2)), yang tentunya diakhiri dengan pembacaan putusan (Pasal 13).

Selain harus mengikuti prosedur hukum acara sebagaimana diatur dalam Pasal 28 sampai dengan Pasal 85 UU No. 24 Tahun 2003 dan PMK No. 15 Tahun 2008, proses penanganan perkara di Mahkamah Konstitusi termasuk proses penanganan perkara perselisihan hasil Pemilu kepala daerah juga harus tunduk pada asas-asas peradilan, baik yang telah diatur dalam undang-undang, hukum acara, undang-undang kekuasaan kehakiman, maupun yang telah diakui secara universal. Beberapa asas-asas peradilan tersebut dijelaskan di bawah ini. ${ }^{28}$

Pertama, persidangan terbuka untuk umum. Pasal 19 UU No. 4 Tahun 2004 tentang Kekuasaan Kehakiman menetukan bahwa sidang pemeriksaan pengadilan adalah terbuka untuk umum, kecuali undang-undang menentukan lain. Ketentuan ini berlaku secara uni-

\footnotetext{
${ }^{28}$ Maruarar, Siahaan, 2005. Hukum Acara Mahkamah Konstitusi Republik Indonesia, Cetakan Pertama, Jakarta: Konstitusi Press, hlm. 54.
} 
versal dan disemua lingkungan peradilan. Pasal 40 ayat (1) UU No. 24 Tahun 2003 tentang MK juga menentukan bahwa sidang MK terbuka untuk umum, kecuali rapat permusyawaratan hakim (RPH). Asas ini harus dilaksanakan, karena berkenaan salah satu bentuk pengawasan masyarakat terhadap proses peradilan dalam kehidupan bernegara. Asas ini tidak hanya terbatas pada pokok perkara semata, tetapi juga menyentuh aspek akuntabilitas hakim, sekaligus institusi peradilan sebagai penyelenggara kekuasaan kehakiman.

Kedua, independen dan imparsial. Pasal 2 UU No. 24 tahun 2003 menyatakan bahwa MK merupakan salah satu lembaga negara yang melakukan kekuasaan kehakiman yang merdeka untuk menyelenggarakan peradilan guna menegakkan hukum dan keadilan. Dalam pasal 33 UU No. 4 tahun 2004 tentang Kekuasaan Kehakiman juga dinyatakan bahwa dalam menjalankan tugas dan fungsinya hakim wajib menjaga kemandirian peradilan. Berdasarkan dua UU tersebut, independensi dan kemandirian erat hubu-ngan dengan sikap hakim imparsial atau tidak memihak, baik dalam proses pemeriksaan maupun pengambilan keputusan. Independensi dan imparsialitas ini tidak hanya secara institusional, tetap secara individual para hakim tetap harus mandiri dan tidak memihak dalam menjalankan proses peradilan guna menegakkan hukum dan keadilan.

Ketiga, peradilan dilaksanakan secara cepat, sederhana, dan biaya murah. Pasal 4 ayat (2) UU No. 4 Tahun 2004 tentang Kekuasaan Kehakiman menyatakan bahwa peradilan dilakukan dengan sederhana, cepat, dan biaya ringan. Dalam praktik, biaya perkara di Mahkamah Konstitusi yang dibebankan kepada pemohon atau termohon atau pihak terkait tidak dikenal. Semua biaya yang menyangkut persidangan di Mah-kamah Konstitusi dibebankan kepada negara. Bahkan panggilan untuk menghadiri persidangan serta salinan putusan yang dimohon oleh pihak pemohon disediakan atas biaya Mahkamah Konstitusi.

Keempat, hak untuk didengar secara seimbang (audi et alteram partem). Penangan perkara perselisihan hasil pemilu kepala dae- rah oleh MK, harus mendengar keterangan seluruh pihak-pihak terkait, yaitu pemohon, termohon, dan pihak terkait lainnya jika ada. Semuanya harus diberi hak yang sama untuk menyampaikan keterangannya, karena jika tidak, akan menimbulkan kesan bahwa hakim MK telah tidak adil dalam persidangan.

Kelima, hakim aktif juga pasif dalam proses persidangan. Karekteristik perkara konstitusi yang kental dengan kepentingan publik telah menyebabkan persidangan tidak dapat diserahkan hanya kepada inisiatif pihakpihak. Hakim MK bersifat pasif dan tidak boleh berinisiatif untuk memeriksa perkara yang tanpa diajukan dengan suatu permohonan oleh pihak-pihak yang berhak. Akan tetapi, jika permohonan sudah didaftar dan mulai diperiksa, hakim akan bersikap aktif dan tidak menggantungkan proses hanya pada inisiatif pihakpihak, baik dalam menggali keterangan mau pun bukti yang dianggap perlu untuk membuat jelas dan terang hal yang diajukan dalam permohonan. Dengan asas ini pula, maka hakim MK dapat memutus berbeda dari yang diminta oleh para pihak sesuai dengan fakta dan buktibukti yang terungkap dalam persidangan.

Keenam, pengadilan mengetahui hukumnya (ius curia novit). Pasal 16 ayat (1) UU No. 4 Tahun 2004 tentang Kekuasaan Kehakiman menyebutkan bahwa pengadilan tidak boleh menolak untuk memeriksa, mengadili dan memutus suatu perkara yang diajukan dengan dalih bahwa hukum tidak ada atau kurang jelas melainkan wajib memeriksa dan mengadilinya. Asas ini secara tegas mengabstraksikan bahwa pengadilan dianggap mengetahui hukum yang menjadi dasar penyelesaian suatu perkara. Akan tetapi tentunya pelaksanaan asas ini tetap harus didasarkan kepada kewenangan yang dimilik oleh Mahkamah Konstitusi.

\section{Sistem Pembuktian dalam Penanganan Per- kara PHPU Kepala Daerah di MK}

Pembuktian secara etimologi berasal dari kata bukti yang berarti sesuatu yang menyatakan kebenaran suatu peristiwa. Menurut Subekti, pembuktian ialah: meyakinkan hakim tentang kebenaran dalil atau dalil-dalil yang di 
kemukakan dalam suatu persengketaan. Dengan demikian tampaklah bahwa pembuktian itu hanyalah diperlukan dalam persengketaan atau perkara di muka hakim atau pengadilan. Sedangkan menurut Sudikno Mertokusumo, pembuktian mempunyai beberapa pengertian, yaitu arti logis, arti konvensional, dan arti yuridis, dengan penjelasan sebagai berikut. ${ }^{29}$

Pertama, pembuktian dalam arti logis adalah memberikan kepastian yang bersifat mutlak karena berlaku bagi setiap orang dan tidak memungkinkan adanya bukti lawan. Contohnya adalah berdasarkan aksioma bahwa dua garis yang sejajar tidak mungkin bersilang. Kedua, pembuktian dalam arti konvensional ialah memberikan kepastian yang bersifat nisbi atau relatif dengan tingkatan sebagai berikut: kepastian yang didasarkan atas perasaan belaka, karena didasarkan atas perasaan maka kepastian ini bersifat intuitif (conviction intime), dan kepastian yang didasarkan atas pertimbangan akal, maka oleh karena itu disebut conviction raisonnce. Ketiga, membuktikan dalam arti yuridis ialah memberi dasar-dasar yang cukup kepada hakim yang memeriksa perkara yang bersangkutan guna memberi kepastian tentang kebenaran peristiwa yang diajukan. Sedangkan tujuan pembuktian adalah untuk menunjukkan kepada hakim alat-alat bukti tertentu, sehingga menimbulkan keyakinan dan kepastian bagi hakim akan adanya fakta-fakta hukum yang disengketakan. Kemudian keyakinan dan kepastian itu akan dijadikan dasar pertimbangan hakim dalam merumuskan putusannya. Seorang hakim baik secara implisit maupun eksplisit harus merumuskan putusannya berdasarkan fakta-fakta dan putusan kenyataan (de feitelijke beslissingen) yang sering sukar dipisahkan dari penilaian hukum oleh hakim.

Sekalipun, kebenaran pembuktian dalam ilmu hukum bersifat relatif, akan tetapi mempunyai nilai yang cukup signifikan bagi para hakim. Hakim akan selalu berpedoman dalam menjatuhkan putusannya dari hasil pembuktian ini. Oleh karena itu acara pembuktian

\footnotetext{
${ }^{29}$ Sudikno Mertokusumo, 1988, Hukum Acara Perdata Indonesia, Yogyakarta: Liberty, hlm. 103-104.
}

menempati posisi penting dari jalannya persidangan di pengadilan, sedangkan dalam menilai kekuatan pembuktian dari alat-alat bukti yang ada, menurut Andi Hamzah, dikenal beberapa sistem atau teori pembuktian.

Pertama, undang-undang positif (positif wettwlijks theorie). Pembuktian yang didasarkan selalu kepada alat-alat pembuktian yang disebut undang-undang. Dalam teori ini undang-undang menentukan alat bukti yang dipakai oleh hakim cara bagaimana hakim dapat mempergunakannya, asal alat-alat bukti itu telah diapakai secara yang ditentukan oleh undang-undang, maka hakim harus dan berwenang untuk menetapkan terbukti atau tidaknya suatu perkara yang diperiksamya. Walaupun barangkali hakim sendiri belum begitu yakin atas kebenaran putusannya itu. Sebaliknya bila tidak dipenuhi persyaratan tentang cara-cara mempergunakan alat-alat bukti itu sebagaimana ditetapkan undang-undang bahwa putusan itu harus berbunyi tentang sesuatu yang tidak dapat dibuktikan tersebut.

Kedua, teori pembuktian berdasarkan keyakinan hakim saja (conviction in time). Berhadap-hadapan secara berlawanan dengan teori pembuktian menurut undang-undang secara positif ialah teori pembuktian menurut keyakinan hakim semata. Didasari bahwa alat bukti berupa pengakuan terdakwa sendiripun tidak selalu membuktikan kebenaran. Pengakuan kadang-kadang tidak menjamin terdakwa benar-benar telah melakukan perbuatan yang didakwakan. Bertolak pangkal pada pemikiran itulah, maka teori berdasarkan keyakinan hakim semata yang didasarkan kepada keyakinan hati nuraninya sendiri ditetapkan bahwa terdakwa telah melakukan perbuatan yang didakwakan. Dengan sistem ini, pemidanaan dimungkinkan tanpa didasarkan kepada alat-alat bukti dalam undang-undang. Dari mana hakim menyimpulkan putusannya tidak menjadi masalah. Hakim boleh menyimpulkan dari alat bukti yang ada di dalam persidangan atau mengabaikan alat bukti yang ada.

Ketiga, teori pembuktian berdasarkan keyakinan hakim atas alasan yang logis (la conviction in raisonne). Sistem atau teori yang di- 
sebut pembuktian yang berdasarkan keyakinan hakim sampai batas tertentu atau atas alasan yang logis (la conviction raisonnee ). Menurut teori ini, hakim dapat memutuskan seseorang bersalah berdasarkan keyakinannya, keyakinan yang didasarkan kepada dasar-dasar pembuktian diserta dengan suatu kesimpulan yang berlandaskan kepada peraturan-peraturan pembuktian tertentu. Miskipun alat-alat bukti telah ditetapkan oleh undang-undang, tetapi hakim bisa menggunakan alat-alat bukti diluar yang ditentukan oleh undang-undang, namun demikian didalam mengambil keputusan haruslah tetap didasarkan pada alasan-alasan yang jelas. Oleh karena itu maka putusan tersebut juga harus didasarkan pada alasan yang diterima akal sehat (reasonable). Sistem pembuktian ini juga sering disebut dengan sistem pembuktian bebas atau vrij bewijs.

Keempat, teori pembuktian berdasarkan undang-undang secara negatif (negative wettelijk). Sistem pembuktian ini mirip dengan simtem pembuktian conviction ini raisone, hakim dalam mengambil keputusan terikat oleh alat bukti yang telah ditentukan oleh undangundang dan keyakinan (nurani) hakim sendiri. Jadi di dalam sistem ini ada dua hal yang merupakan syarat untuk membuktikan dalam mengambil keputusan, yaitu: wettelijk, artinya harus ada alat bukti yang sah yang telah ditentukan oleh undang-undang; dan negatief artinya adanya keyakinan hakim yang didasarkan pada alat bukti tersebut.

Dari keempat sisitem pembuktian diatas, sistem pembuktian manakah yang dianut oleh MK dalam penangan perkara perselisihan hasil pemilihan umum kepala daerah? Untuk menjawab pertanyaan ini tentunya harus kita lihat pada ketentuan UU No. 24 Tahun 2003 tentang MK khususnya pasal-pasal yang mengatur tentang hukum acara yang diatur dalam pasal 28 sampai dengan pasal 85, PMK No. 15 Tahun 2008 tentang Pedoman Beracara Dalam PerseIisihan Hasil Pemilihan Umum Kepala Daerah khususnya Pasal 8 sampai Pasal 11, serta dengan melihat praktek pelaksanaan persidangan dengan agenda pembuktian dalam perkara PHPU Pemilukada di Mahkamah Konstitusi.
Menurut hemat penulis paling tidak ada enam pasal dan sepuluh ayat dalam UU No. 24 Tahun 2003 tentang Mahkamah Konstitusi yang dapat dikaji untuk dapat mengetahui dan menentukan sistem pembuktian yang dianut oleh Mahkamah Konstitusi. Pertama, Pasal 36, yang terdiri dari Pasal 36 ayat (1) dan ayat (4). Pasal 36 ayat (1) menentukan bahwa yang di sebut alat bukti di antaranya adalah surat atau tulisan; keterangan saksi; keterangan ahli; keterangan para pihak; petunjuk; dan alat bukti lain berupa informasi yang diucapkan, dikirimkan, diterima, atau disimpan secara elektronik dengan alat optik atau yang serupa dengan itu. Pasal 36 ayat (4) menentukan bahwa MK menentukan sah atau tidak sahnya alat bukti dalam persidangan Mahkamah Konstitusi. Dalam pasal ini jelas diatur tentang macam-macam alat bukti, artinya sistem pembuktian di Mahkamah Konstitusi memerlukan alat bukti tidak semata-mata keyakinan hakim semata sebagaimana dalam sistem conviction intime. Selain itu Mahkamah Konstitusi juga diberi kewenangan untuk menilai sah atau tidak sahnya suatu alat bukti yang diajukan oleh para pihak. Jadi tidak semua alat bukti yang diajukan oleh para pihak langsung diterima begitu saja hanya karena kesesuaianya dengan ketentuan undang-undang sebagaimana dalam sistem pembuktian positif.

Kedua, Pasal 37, berdasarkan pasal ini, Mahkamah Konstitusi menilai alat-alat bukti yang diajukan ke persidangan dengan memperhatikan persesuaian antara alat bukti yang satu dengan alat bukti yang lain. Di sini Mahkamah Konstitusi juga diberi kewenangan untuk menilai kesesuaian alat bukti yang diajukan oleh para pihak. Jadi tidak semua alat bukti yang diajukan oleh para pihak langsung diterima begitu saja hanya karena kesesuaianya dengan ketentuan undang-undang sebagaimana dalam sistem pembuktian positif.

Ketiga, Pasal 38 ayat (1), yang menentukan bahwa para pihak, saksi, dan ahli wajib hadir memenuhi panggilan Mahkamah Konstitusi. Pasal 38 ayat (4) menegaskan bahwa jika saksi tidak hadir tanpa alasan yang sah meskipun sudah dipanggil secara patut menurut 
hukum, MK dapat meminta bantuan kepolisian untuk menghadirkan saksi tersebut secara paksa. Dengan ketentuan pasal ini, selain para pihak, hakim MK juga dapat memanggil saksi dan/atau ahli yang diperlukan keterangannya. Jadi hakim MK tidak pasif hanya menilai apa yang diajukan oleh para pihak tapi juga bebas dan aktif untuk memanggil dan mendengarkan keterangan saksi dan/atau ahli yang diperlukan.

Keempat, Pasal 41 ayat (1), yang menentukan bahwa dalam persidangan hakim konstitusi memeriksa permohonan beserta alat bukti yang diajukan. Kelima, Pasal 42, di mana ditenukan saksi dan ahli yang dipanggil wajib hadir untuk memberikan keterangan. Keenam, Pasal 45 ayat (1), yang menentukan MK memutus perkara berdasarkan UUD 1945 sesuai dengan alat bukti dan keyakinan hakim. Pasal 45 ayat (2): Putusan MK yang mengabulkan permohonan harus didasarkan pada sekurang-kurangnya 2 (dua) alat bukti. Pasal 45 ayat (3): Putusan MK wajib memuat fakta yang terungkap dalam persidangan dan pertimbangan hukum yang menjadi dasar putusan. Dalam pasal ini sudah diatur dengan jelas dan tegas bahwa hakim Mahkamah Konstitusi dalam membuat putusan harus didasarkan pada alat bukti (wettelijk) dan keyakinan hakim (negatief) serta disertai dengan pertimbangan hukum yang reasonable. Jadi tidak cukup jika hanya didasarkan pada alat bukti saja, atau hanya didasarkan pada keyakinan hakim semata sebagaimana dalam sistem conviction in time.

Dilihat dari ketentuan PMK No. 15 Tahun 2008 tentang Pedoman Beracara Dalam Perselisihan Hasil Pemilihan Umum Kepala Daerah yang secara spesifik mengatur tentang Acara Persidangan PHPU Pemilukada yang didalamnya juga terkait dengan sistem pembuktian, maka setidaknya ada empat pasal yang dapat dikaji untuk dapat menentukan sistem pembuktian yang dilakukan oleh Mahkamah Konstitusi dalam menangani perkara PHPU Pemilukada. Pertama, Pasal 8 ayat (2), yang menentukan bahwa proses pemeriksaan persidangan dilakukan dengan tahapan sebagai berikut: penjelasan permohonan dan perbaikan apabila dipandang perlu; jawaban termohon; keterangan pihak terkait apabila ada; pembuktian oleh pemohon, termohon, dan pihak terkait; dan kesimpulan.

Pasal di atas juga mengatur salah satu tahapan persidangan dalam penanganan perkara PHPU Pemilukada oleh MK adalah tahapan pembuktian baik oleh pemohon, termohon, maupun pihak terkait. Jadi jelas dengan ketentuan ini pembuktian mempunyai peranan signifikan dalam penanganan perkara PHPU Pemilukada di MK, sehingga perlu untuk dimasukkan dalam tahapan persidangan tersendiri. Bahkan untuk kepentingan pelaksanaan tahapan pembuktian ini, agar tidak menyulitkan para pihak yang berperkara dalam ayat (3) nya diatur: Untuk kepentingan pembuktian, Mahkamah dapat melakukan pemeriksaan melalui persidangan jarak jauh (video conference).

Kedua, Pasal 9, yang mengatur mengenai alat bukti dalam perselisihan hasil pemilukada dapat berupa: keterangan pihak terkait; surat atau tulisan; keterangan saksi; keterangan ahli; petunjuk; dan alat bukti lain berupa informasi dan/atau komunikasi elektronik. Ketiga, Pasal 10 ayat (1), yang mengatur mengenai alat bukti surat atau tulisan terdiri dari berita acara dan salinan pengumuman hasil pemungutan suara dari Tempat Pemungutan Suara (TPS); berita acara dan salinan sertifikat hasil penghitungan suara dari Panitia Pemungutan Suara (PPS); berita acara dan salinan rekapitulasi jumlah suara dari Panitia Pemilihan Kecamatan (PPK); berita acara dan salinan rekapitulasi hasil penghitungan suara dari KPU/ KIP provinsi atau kabupaten/kota; berita acara dan salinan penetapan hasil penghitungan suara pasangan calon kepala dan wakil kepala daerah provinsi atau kabupaten/kota; berita acara dan salinan rekapitulasi hasil penghitungan suara dari KPU/KIP propinsi; penetapan calon terpilih dari KPU/ KIP provinsi atau kabupaten/kota; dan/atau dokumen tertulis lainnya. Selain itu Mahkamah Konstitusi juga diberi kewenangan untuk menilai sah atau tidak sahnya suatu alat bukti yang diajukan oleh para pihak. Jadi tidak semua alat bukti yang diajukan oleh para pihak langsung diterima 
begitu saja hanya karena kesesuaianya dengan ketentuan undang-undang sebagai-mana dalam sistem pembuktian positif.

Keempat, Pasal 11 ayat (1), (2), dan (3). Pasal 11 ayat (1) mengatur mengenai saksi dalam perselisihan hasil Pemilukada terdiri dari saksi resmi peserta Pemilukada dan saksi pemantau Pemilukada. Ayat (2) mengatur mengenai kewenangan MK yang dapat memanggil saksi lain yang diperlukan, antara lain, panitia pengawas pemilihan umum atau kepolisian. Ayat (3) mengatur tentang saksi sebagaimana tersebut pada ayat (1) dan ayat (2) adalah saksi yang melihat, mendengar, atau mengalami sendiri proses penghitungan suara yang diperselisihkan.

Berdasarkan pasal ini, selain para pihak, hakim MK juga dapat memanggil saksi dan/ atau ahli yang diperlukan keterangannya. J adi hakim MK tidak pasif hanya menilai apa yang diajukan oleh para pihak tapi juga bebas dan aktif untuk memanggil dan mendengarkan keterangan saksi dan/atau ahli yang diperlukan. Ini menunjukkan bagitu pentingnya tahapan pembuktian dalam penanganan perkara PHPU Pemilukada untuk meyakinkan hakim. Sedangkan dalam praktek penanganan perkara PHPU Pemilukada di MK diantaranya dapat kita lihat pada pembuktian dalam perkara PHPU Pemilukada Gubernur dan Wakil Gubernur Jawa Timur Tahun 2008. Dalam perkara tersebut Pemohon, yaitu pasangan Calon Gubernur dan Wakil Gubernur, Hj. Khofifah Indar Parawansa dan Mudjiono, mendalilkan bahwa telah terjadi kesalahan penghitungan suara di 25 (dua puluh lima) kabupaten/kota di Jawa Timur termasuk empat kabupaten di Madura. Selain itu Pemohon juga mendalikan telah menemukan sejumlah pelanggaran penghitungan suara dalam Pemilukada J awa Timur tahun 2008 Putaran II, yaitu: Pelanggaran di Kab. Pamekasan dalam rekapitulasi suara yang dilakukan di desa, padahal seharusnya di TPS, pelanggaran di Kab. Lamongan, Madiun, Nganjuk, Sidoarjo, Probolinggo, Banyuwangi. ${ }^{30}$ Untuk menguatkan dalil-dalil tersebut, Pemohon telah mengaju-

\footnotetext{
${ }^{30}$ Lihat Putusan Mahkamah Konstitusi, No. 41/ PHPU.D$\mathrm{Vl} / 2008$
}

kan cukup banyak bukti surat atau tertulis sejumlah 101 (seratus satu) alat bukti yang diserahkan dalam persidangan, serta ditambah 31 (tiga puluh satu) alat bukti surat atau tulisan serta berupa rekaman pembicaraan telephone beserta transkripnya yang diserahkan diluar persidangan. Selain itu Pemohon juga menghadirkan bukti lain berupa saksi sebanyak 26 orang.

Untuk menyanggah dalil-dalil dan buktibukti yang diajukan oleh Pemohon, baik Termohon dalam hal ini KPU Propinsi J awa Timur, maupun Pihak Terkait dalam hal ini Pasangan Calon Gubernur dan Wakil Gubernur Jawa Timur Nomor Urut 5, Dr. H. Soekarwo dan Drs. H. Syaifullah Yusuf, sama-sama mengajukan dalil-dalil sanggahan serta alat bukti masingmasing untuk mendukung dalil-dalil sanggahannya. Termohon mengajukan sebanyak 86 bukti tertulis atau surat, serta menghadirkan 15 orang saksi, sedangkan Pihak Terkait untuk menguatkan dalil-dalil sanggahannya terhadap dalil-dalil dan bukti-bukti yang diajukan oleh Pemohon, telah mengajukan sebanyak 16 bukti tertulis atau surat.

Terhadap dalil-dalil yang diajukan Pemohon, serta bukti-bukti dan saksi-saksi yang dihadirkan, MK telah memberikan pertimbangan hukumnya dalam putusan Nomor : 41/ PHPU.D$\mathrm{VI} / 2008$, di antaranya pada halaman 115 angka (3.20) yang menyatakan bahwa bukti-bukti surat dan saksi-saksi yang diajukan untuk mendukung dalil Pemohon tentang Kesalahan dan kekeliruan dalam penghitungan suara di desa, kecamatan dan kabupaten yang diuraikan oleh Pemohon dalam petitum Permohonan, tidak dapat dipandang sebagai bukti yang cukup dan meyakinkan untuk mendukung dalil-dalil permohonan. Meskipun demikian, menurut Mahkamah Konstitusi terdapat bukti yang meyakinkan bahwa telah terjadi penghitungan suara yang keliru, baik proses atau dengan cara menambah atau mengurangi suara (penggelembungan atau penggembosan suara) di Kab. Sampang, Pamekasan, terutama di Kab. Bangkalan, yang justru sama sekali tidak disebut secara spesifik dalam posita maupun petitum permohonan, sehingga dengan alat bukti dan 
keterangan saksi yang dinilai cukup meyakinkan tersebut, MK dalam amar putusannya mengabulkan Peromohonan Pemohon untuk sebagian. ${ }^{31}$ Dari gambaran dalam kasus ini sudah jelas dan tegas bahwa hakim MK dalam membuat putusan tidak hanya ber-dasarkan pada alat bukti semata yang secara peraturan perundang-undangan memenuhi syarat (wettelijk) melainkan alat bukti tersebut juga harus meyakinan hakim (negatief) serta disertai dengan pertimbangan hukum yang reasonable. J adi tidak cukup jika hanya didasarkan pada alat bukti semata-mata sebagaimana dalam sistem pembuktian positif, atau hanya didasarkan pada keyakinan hakim semata sebagaimana dalam sistem conviction in time melainkan harus paduan dari keduanya.

Berdasarkan kajian terhadap UU No. 24 Tahun 2003 dan PMK No. 15 Tahun 2008 serta analisa kasus penangan perkara PHPU Pemilukada Gubernur dan Wakil Gubernur J awa Timur Tahun 2008 diatas, maka dapat disimpulkan bahwa sistem pembuktian yang dianut oleh Mahkamah Konstitsui dalam pena-nganan perkara PHPU Kepala Daerah dan Wakil Kepala Daerah adalah sistem wettelijk negatief atau sistem pembuktian berdasarkan undang-undang secara negatif, sedangkan kebebasan hakim Mahkamah Konstitusi dalam menilai sah atau tidak sahnya suatu alat bukti serta kesesuaiannya dengan alat bukti lainnya, dan kebebasan untuk memanggil saksi atau ahli yang dibutuhkan diluar yang diajukan oleh para pihak diambil dari sistem la conviction in rasione.

\section{Penutup \\ Simpulan}

Berdasarkan pembahasan diatas, maka dapat ditarik simpulan bahwa yang dimaksud dengan pembuktian adalah meyakinkan hakim tentang kebenaran dalil yang di kemukakan dalam suatu persengketaan. Dengan demikian tampaklah bahwa pembuktian itu hanyalah diperlukan dalam persengketaan atau perkara di muka hakim atau pengadilan. Adapun tujuan pembuktian adalah untuk menunjukkan kepada hakim alat-alat bukti tertentu, sehingga menimbulkan keyakinan dan kepastian bagi hakim akan adanya fakta-fakta hukum yang disengketakan. Kemudian keyakinan dan kepastian itu akan dijadikan dasar pertimbangan hakim dalam merumuskan putusannya. Adapun sistem pembuktian yang dianut oleh Mahkamah Konstitsui dalam penangan perkara perselisihan hasil pemilihan umum kepala daerah dan perkara lainnya yang menjadi kewenangan Mahkamah Konstitusi adalah sistem Wettelijk Negatief atau sistem pembuktian berdasarkan undang-undang secara negatif, sedangkan kebebasan hakim Mahkamah Konstitusi dalam menilai sah atau tidak sah nya suatu alat bukti serta kesesuaiannya dengan alat bukti lainnya, dan kebebasan untuk memanggil saksi atau ahli yang dibutuhkan, diluar yang diajukan oleh para pihak diambil dari sistem la conviction in rasione.

\section{Saran}

Pilihan sistem pembuktian dalam penanganan perkara PHPU Kepala Daerah di MK, yaitu wettelijk negatief serta dilengkapi dengan pendekatan teori la conviction in rasione sudah cukup tepat dan perlu dipertahankan. Mengingat menurut hemat penulis sistem sistem tersebut yang dapat lebih menjamin tegaknya keadilan dalam penegakan hukum.

\section{Daftar Pustaka}

Ardilafiza. "Pemilu Yang Demokratis?", J urnal Konstitusi Vol. II, No. 1, J uni 2009. PKKFH Universitas Bengkulu;

Budiana, I Nyoman. "Reinterpretasi Sistem Pemilu sebagai Implementasi Kedaulatan Rakyat Di Indonesia". J urnal Konstitusi Vol. Ii, No. 1, J uni 2009. PKK Fakultas Hukum Universitas Pattimura;

Ekatjahjana, Widodo. "Tinjauan Tentang Mekanisme Penyelesaian Perselisihan Hasil Pemilu Anggota DPR, DPD dan DPRD Berdasarkan Peraturan Mk No. 16 Tahun 2009", J urnal Konstitusi Vol. II, No. 1, J uni 2009. PKKKD-FH Universitas Muhammadiyah Magelang; 
Fajar, A. Mukhtie. "Pemilu yang Demokratis dan Berkualitas: Penyelesaian Hukum Pelanggaran Pemilu dan PHPU". Jurnal Konstitusi, Vol. 6 Nomor 1, April 2009;

Faqih, Mariyadi. "Nilai-Nilai Filosofi Putusan Mahkamah Konstitusi Yang Final dan Mengikat". J urnal Konstitusi, Vol. 7, Nomor 3, J uni 2010;

Ghoffar, Abdul. "Kejujuran dalam Bingkai Hak Memilih-Dipilih (Pelajaran dari Pemilukada Bengkulu Selatan)". J urnal Konstitusi, Vol. 8, No. 1, Februari 2011;

Hoesein, Zainal Arifin. "Pemilu Kepala Daerah dalam Transisi Demokrasi". J urnal Konstitusi, Vol. 7, Nomor 6, Desember 2010;

J unaidi, Veri. "Menata Sistem Penegakan Hukum Pemilu Demokratis Tinjauan Kewenangan MK atas Penyelesaian Perselisihan Hasil Pemilu". Jurnal Konstitusi, Vol. 6, Nomor 3, September 2009;

"Pelanggaran Sistematis, Terstruktur dan Masif: Suatu Sebab Pembatalan Kehendak Rakyat dalam Pemilihan Kepala Daerah Tahun 2010". J urnal Konstitusi, Vol. 7, Nomor 5, Oktober 2010;

Malik. “Telaah Makna Hukum Putusan Mah- kamah Konstitusi yang Final dan Mengikat". J urnal Konstitusi, Vol. 6, Nomor 1, April 2009;

Saraswati, Retno. "Calon Perseorangan Dalam Pilkada Suatu Tinjauan Filosofis". J urnal Konstitusi Vol. II, No. 1, J uni 2009. PPK Fakultas Hukum Universitas Brawij aya;

Siahaan, Maruarar. 2005. Hukum Acara Mahkamah Kons-titusi Republik Indonesia. Cetakan Pertama. Jakarta: Konstitusi Press;

Sudrajat, Hendra. “Kewenangan Mahkamah Konstitusi Mengadili Perselisihan Hasil Pemilukada". J urnal Konstitusi, Volume 7, Nomor 4, Agustus 2010;

Sukriono, Didik. "Menggagas Sistem Pemilihan Umum Di Indonesia". Jurnal Konstitusi Vol. II, No. 1 J uni 2009. PKK Universitas Kanjuruhan Malang;

Syahuri, Taufi Qurrohman. "Putusan Mahkamah Konstitusi Tentang Perselisihan Hasil Penghitungan Suara Pemilihan Umum Berdasarkan Undang-Undang No. 24 Tahun 2003". Jurnal Konstitusi Vol. II, No. 1, J uni 2009. PKK-FH Universitas Bengkulu. 
